FACTA UNIVERSITATIS

Series: Economics and Organization Vol. 16, N ${ }^{\circ}$ 4, 2019, pp. 377 - 387

https://doi.org/10.22190/FUEO1904377M

Original Scientific Paper

\title{
CREATIVE ACTIVITIES VALUATION USING A TOPSIS - BASED DECISION SUPPORT ALGORITHM
}

\author{
UDC 338.48
}

\author{
Emilia Madudova ${ }^{1}$, Zuzana Palencikova $^{2}$ \\ ${ }^{1}$ University of Žilina, Faculty of Operation and Economics of Transport and \\ Communications, Department of Communications, Slovak Republic \\ ${ }^{2}$ Constantine the Philosopher University in Nitra, Faculty of Central European Studies, \\ Department of Tourism, Slovak Republic
}

\begin{abstract}
The main goal of the paper is the creative activities valuation using a TOPSIS based decision support algorithm. As defined by Cutler \& Carmichael (2010) tourist experience remains in memory, preceded by motivations and expectations and result in satisfaction or dissatisfaction. The creative tourism is not well developed in the Slovak Republic yet, and there is no theoretical evidence what kind of creative tourism activities the tourists are most interested in. As the results show, tourists very strongly prefer creative tourism activities connected to education. The results also show that tourists do not connect creative activities with tourist destinations, which should result in a more involved supply side in the future, with the support of the local economy and sustainability, including the crafts, art and local culture.
\end{abstract}

Key words: creative tourism, tourism, tourism development, competitiveness TOPSIS

JEL Classification: L83, Z32, Z19

\section{INTRODUCTION}

Products and services are no longer enough to generate economic prosperity. Therefore, "organizations use the experience as a management tool for differentiation" (Pine \& Gilmore, 1998). Experiences are "subjective, highly personal and intangible phenomena" (Billing \& O'Dell, 2010), hence, difficult to define and to grasp their essence. The tourist

Received July 15, 2019 / Revised August 28, 2019 / Accepted September 03, 2019

Corresponding author: Emilia Madudova

University of Žilina, Faculty of Operation and Economics of Transport and Communications, Department of Communications, Univerzitná 8215/1 01026 Žilina, Slovak Republic

E-mail: emilia.madudova@fpedas.uniza.sk 
experience "remains in the memory, preceded by motivations and expectations, and results in satisfaction or dissatisfaction" (Cutler \& Carmichael, 2010).

The research of Coelho et al. (2018) shows, that "the experiences seem to arouse a set of emotions and not just an isolated one. Furthermore, memorable experiences have resulted primarily in positive emotions, to the inward (reward, freedom) or outward (joy, happiness, enthusiasm, liveliness)". Figure 1 illustrates the kind of emotions arising from memorable tourism experiences.

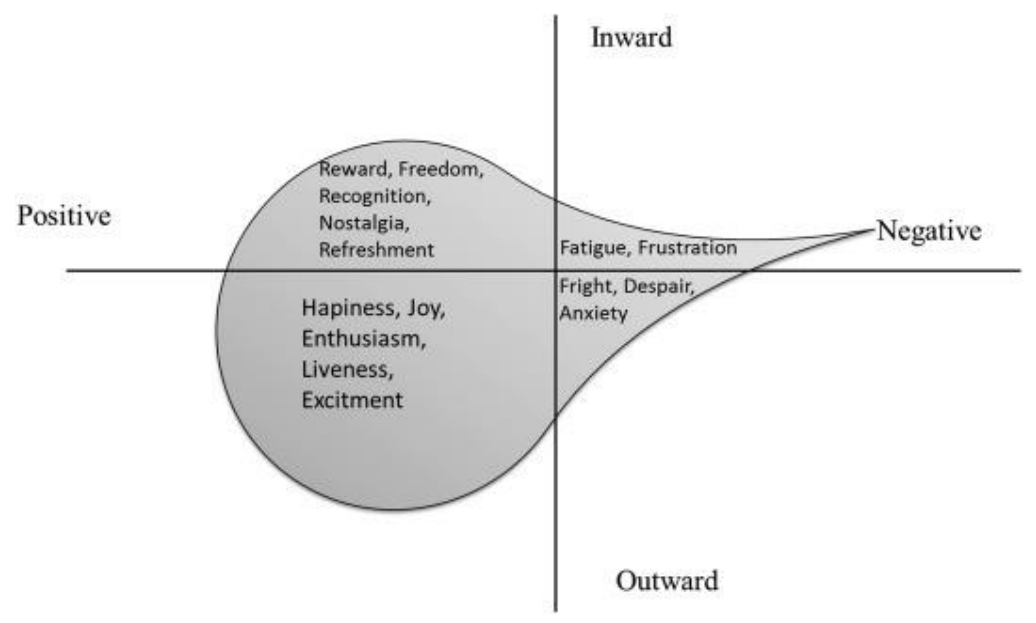

Fig. 1 Representation of the types of emotions of Memorable Travel Experiences Source: Coelho et al. 2018

Tan et al (2013) consider experience as "a process that tourists need to go through to achieve creativity". They integrate six categories of experiences into four themes: 'consciousness/awareness', 'creativity', 'needs', and 'learning and interacting', as shown in Figure 2. "The first three are named 'inner reflection's as the reflexive process happens to the inner-self; and the final theme is named 'outer interactions, because tourists are interacting with outside factors, such as the environment, people, and product/service/ experience. In addition, 'consciousness/awareness' is a prerequisite of creative experience, and the tourists must have a sense of this (whether individual, social, cultural or environmental)" in order to have a creative experience, as this differentiates these from other experiences. The findings show that 'outer interactions' and 'inner reflections' together construct the model of 'creative experience'.

This is consistent with the view that 'self-actualization, learning, creativity, and needs operate in a synergistic cycle' (Burleson, 2005), as well as Hanifl's idea that people are creating, designing, selecting and reflecting upon their creative experiences (2015).

In order to understand the origins of creative tourism, one needs "first to look at the rise of culture as a form of tourism consumption" (Richards, 2013; Carvalho et al., 2019; Csapó 2012). The characteristics of tourism's current consumption demonstrate that it has increasingly acquired a diverse, multidimensional and (micro) segmented character, 
corresponding to broader use of culture (Jelincic, 2009). "Understanding the role of creativity in the tourism industry, and how it contributes to creative experiences, is both challenging and complex. Creativity can be seen in multiple dimensions: everyday creativity, artistic creativity, and intellectual creativity" (Ivcevic \& Mayer, 2009).

Tourists stand to benefit from stretching their capabilities and learning new skills, possibilities which work pressures in the home environment often leave little time for. People increasingly feel a need to distinguish themselves in a homogenized world and are becoming more curious about the relative process (Richards \& Raymond 2000).

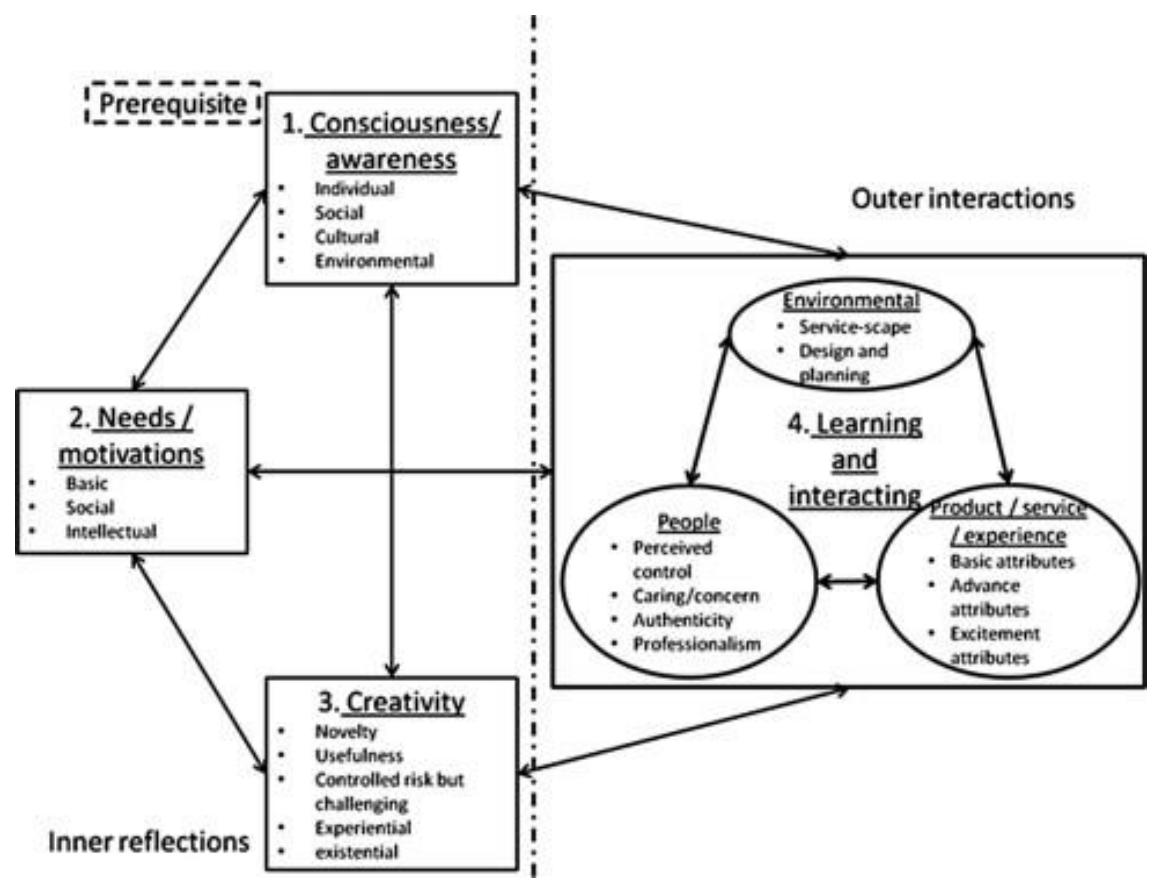

Fig. 2 A model of creative experience

Source: Tan et al. 2013

Creative tourism stands for the acquisition of certain skills during holidays, which becomes a part of the culture and community of a target country. UNESCO's Creative Cities Network (2006) understands "creative tourism as travel directed toward an engaged and authentic experience, with participative learning in the arts, heritage, or special character of a place" in connection with residents. "Tourists develop their creative potential and become closer to the local community through informal participation in interactive seminars and acquisition of experience" (Raymond, 2007). "Creative tourism is a trip directly oriented towards participation and acquisition of authentic experience, gaining certain knowledge in the field of arts, heritage and particular kind of locations where immediate communication with the local community is possible, which would allow creating a 'live' culture" (Maisel, 2009). 
"Creative tourism can be seen in numerous situations where visitors, service providers, and the local community exchange ideas and skills and influence each other in a synergetic way. In this sense, creative tourism can be (Richards \& Marques 2012):

- a means of involving tourists in the creative life of the destination,

- a creative means of using existing resources,

- a means of strengthening identity and distinctiveness,

- a form of self-expression/discovery,

- a form of edutainment -self-realization and education,

- a source of ,atmosphere” for places,

- a source of recreating and reviving places."

Even though creativity is seen as the base of creative tourism, the creative factors of creative tourism systems remain unexplored. Furthermore, the current definitions of creative tourism are all supply-led, such as by tourism boards, service providers, and various industry practitioners, without considering the tourists' viewpoint although tourists are seen as co-creators of the experiences.

As Kaufman \& Baer (2012) ask, who decides what is creative? However, according to Tan et al. (2013) all creativity assessments are "expert-based, and may not be applicable for ordinary people, especially the research studies often examine artistic creative dimensions that are unreachable by lay people, such as tourists, who just want to enjoy something that is original or authentic in common life settings and related interactions."

Nature of creative supply is synergetic and it lies in the offer of creative activities by "locals" (service providers, creative communities) through which visitors can develop their creative potential and locals can improve their position on the market place (Hrubalova \& Palencikova, 2017).

"Although tourists are playing active roles in co-creating their experiences while on vacation, industry practitioners still take the lead when it comes to designing and providing such activities" (Raymond, 2007), with few studies considering what tourists actually want in this context. For example, Maitland (2008) studies the roles of tourists and residents in creative cities, while Maisel (2009) acknowledges that many tourists desire experiences that are small, intimate and on a human scale.

The original concept of Richards \& Raymonds creative tourism (2000) with an emphasis on creative learning through attending courses and workshops while on holiday has shifted to the current concept of co-creation as co-makers between the visitors and the locals, to "living like local" experience integrating all aspects of tourist consumption at creative places/destinations (Palencikova, 2018).

There is a need for more analysis of creative tourism in the Slovak Republic, which draws on the tourists perspective, especially with regard to what kind of activities do tourists prefer and consequently, which of the activities will they go for. The paper also explores the assumption of Maisel (2009) that creative activity should be directly oriented towards authentic experience, knowledge connected with the location/region and the local community.

\section{Methodology}

The scope of the research was to evaluate the interest of Slovak tourists for creative tourism activities, to identify their selection criteria, using a TOPSIS based algorithm. A 
questionnaire has been applied as the data collection instrument. Data from respondents were collected during the spring season 2019 (from January to May) in various tourist regions in Slovakia. The direct inquiry was carried out on a sample of 315 respondents from all the regions of the Slovak Republic, aged 15-75. The respondents were to mark the category (specification) connected with creative tourism activity related to importance. (Table 3 ).

TOPSIS is a bipolar comparison of each alternative under consideration with both the positive ideal (PIS) and the negative ideal (NIS) solutions. The distances to these two solutions are calculated for each alternative and then the aggregated criterion is built that combines these two factors and describes the quality of each alternative, assuming that the chosen alternative should have the shortest distance to the ideal solution and the farthest distance to the negative ideal one (Wachowicz, 2011).

In order to calculate the weights for the different criteria, the AHP (Analytic Hierarchy Process), introduced by Thomas Saaty (1996) has been applied. In this AHP, the pairwise comparison matrix $\mathrm{A}$ is built. The matrix $\mathrm{A}$ is an $m^{\mathrm{x}} m$ real matrix, where $\mathrm{m}$ is the number of evaluation criteria considered. Relative importance between two criteria are measured according to a numerical scale from 1to 9. (Table 1)

The pairwise comparison was evaluated according to our survey (inquiry) results. The direct inquiry was carried out on a sample of 315 respondents from the Slovak Republic, aged 15-75 from all the regions of the Slovak Republic. The respondents were to mark the category (specification) connected with creative tourism activity related to importance. (Table 3).

Table 1 AHP criteria evaluation

\begin{tabular}{cl}
\hline Value _ $S_{i j}$ & Interpretation \\
\hline 1 & i and j are equally important \\
3 & i is slightly more important than $\mathrm{j}$ \\
5 & i is more important than $\mathrm{j}$ \\
7 & i is strongly more important than $\mathrm{j}$ \\
9 & i is absolutely more important than $\mathrm{j}$ \\
\hline
\end{tabular}

Each entry $S_{i j}$ of the matrix A represents the importance of the $i$-th criterion relative to the $j$-th criterion. If $S_{i j}>1$, then the $i$-th criterion is more important than the $j$-th, where $S_{i i}=1, i=1,2,3 \ldots, k$ and $S_{j i}=1 / S_{i j}$.

Finally, the criteria weight vector $v_{i}$ (that is an m-dimensional column vector) is built in three partial steps. (1) - (3),

$$
S_{i}=\prod_{j=1}^{k} S_{i j}
$$

where $k$ in number of criteria, $S_{i j}-$ is criteria,

$$
\begin{gathered}
R_{i}=\left(S_{i}\right)^{1 / k} \\
v_{i}=\frac{R_{i}}{\sum_{i=1}^{k} R_{i}}
\end{gathered}
$$

where, $j=1,2, \ldots, k$. 
The TOPSIS algorithm consists of six subsequent steps:

1. Building the normalized decision matrix $R=\left(r_{i j}\right)$,

where $i=1,2,3 \ldots k, j=1,2,3 \ldots k$.

$$
r_{i, j}=\frac{y_{i j}}{\sqrt{\sum_{i=1}^{k} y_{i j}^{2}}}
$$

2. Computing the weighted normalized decision matrix. Each $j$-th column of $R$ matrix multiply by $v_{j}$ weight and calculate weighted normalized decision matrix $W$.

3. Determinig the positive ideal $H_{j}$ and negative ideal $D_{j}$ solutions, where $H_{j}=\max w_{i j}$, $j=1,2,3 \ldots, k$ and $D_{j}=\min w_{i j}, j=1,2,3 \ldots, k$.

4. Calculating the separation measures (distance) for each alternative $i$ and the best condition $d_{j}^{+}$and distance from the target alternative $i$ to the worst condition. $\mathrm{d}_{\mathrm{j}}{ }^{-}$, the Euclidean distance is used:

$$
\begin{aligned}
& d_{i}^{+}=\sqrt{\sum_{j=1}^{k}\left|w_{i j}-H_{j}\right|^{2}}, \text { for } i=1,2, \ldots, k \\
& d_{i}^{-}=\sqrt{\sum_{j=1}^{k}\left|w_{i j}-D_{j}\right|^{2}}, \text { for } i=1,2, \ldots, k
\end{aligned}
$$

5. Determining the relative closeness of each alternative to the ideal solution:

$$
c_{i}=\frac{d_{i}^{-}}{d_{i}^{+}-d_{i}^{-}}, \text {for } i=1,2, \ldots, k
$$

6. Ranking the alternatives in descending order using $c_{i}$.

\section{RESULTS}

This section presents a numerical case study of creative tourism activities classification in the Slovak Republic to demonstrate the proposed creative activity selection algorithm.

Activities related to creative tourism in the Slovak Republic were divided into several categories. The main categories are events, courses, and workshops. The more detailed specification of activities is described in Table 2.

Table 2 Creative tourism activities

\begin{tabular}{lc}
\hline Category & Activity \\
\hline Events with the theme of traditional crafts and folk art & $\mathrm{a}_{1}$ \\
Courses of traditional crafts and folk art & $\mathrm{a}_{2}$ \\
Gastronomic events with the theme of cooking local dishes and meals & $\mathrm{a}_{3}$ \\
Cooking courses of cooking local dishes and meals & $\mathrm{a}_{4}$ \\
Events associated with demonstrations of authentic folklore & $\mathrm{a}_{5}$ \\
Scenic Art Courses & $\mathrm{a}_{6}$ \\
Visual Art Courses & $\mathrm{a}_{7}$ \\
Workshops designed for children & $\mathrm{a}_{8}$ \\
Courses of recycling and production of organic products (Eco-friendly products) & $\mathrm{a}_{9}$ \\
\hline \multicolumn{2}{c}{ Source: Authors } \\
\hline
\end{tabular}


In order to compare selected activities, it is necessary to identify the criteria (Table 3), most characterizing the creative tourism activities. As described in the methodology, in contemplation of calculating the weights for the different criteria, the analytic hierarchy process with pairwise comparison was applied. In criteria evaluating, the results of the survey (more described in the methodology) were taken into account. Conforming to research (inquiry) results, respondents strongly favored creative tourism activity connected to education. Based on the results, the creative tourism activity should be funny and relaxing, authentic, unique and challenging. Destination, respectively linking to a particular location is not a key factor in the choice of creative tourism activity for respondents.

Table 3 Creative tourism activity selection criteria

\begin{tabular}{|c|c|c|c|}
\hline Criterion description & Criterion name & Category & Survey \\
\hline $\begin{array}{l}\text { - Educate, } \\
\text { - learn to unfold skills and techniques, } \\
\text { - acquire or develop new skills. }\end{array}$ & EDUCATION & $\mathrm{K}_{1}$ & $\begin{array}{c}\text { Very } \\
\text { strongly } \\
\text { preferred }\end{array}$ \\
\hline - Be funny & $\begin{array}{c}\text { FUN AND } \\
\text { RELAXATION }\end{array}$ & $\mathrm{K}_{2}$ & $\begin{array}{l}\text { Strongly } \\
\text { preferred }\end{array}$ \\
\hline $\begin{array}{l}\text { Referring to the location, } \\
\text { - a better understanding of the local culture, } \\
\text { become closer to the local community. }\end{array}$ & $\begin{array}{l}\text { LINKED TO } \\
\text { DESTINATION }\end{array}$ & $\mathrm{K}_{3}$ & $\begin{array}{l}\text { Weakly } \\
\text { preferred }\end{array}$ \\
\hline $\begin{array}{l}\text { - Be unique and extraordinary, } \\
\text { - enable to get an authentic experience. }\end{array}$ & $\begin{array}{l}\text { AUTHENTIC AND } \\
\text { UNIQUE }\end{array}$ & $\mathrm{K}_{4}$ & $\begin{array}{l}\text { Strongly } \\
\text { preferred }\end{array}$ \\
\hline - Challenging and unusual. & CHALLENGE & $\mathrm{K}_{5}$ & $\begin{array}{l}\text { Strongly } \\
\text { preferred }\end{array}$ \\
\hline
\end{tabular}

Source: Authors

In the next step, the pairwise comparison matrix was built (Table 4). Relative importance between two criteria was measured according to a numerical scale from 1 to 9 and according to survey results. Each criterion was evaluated according to survey results (methodology).

Table 4 Pairwise comparison of creative tourism activities

\begin{tabular}{ccccccccc}
\hline Criterion & $\mathrm{K}_{1}$ & $\mathrm{~K}_{2}$ & $\mathrm{~K}_{3}$ & $\mathrm{~K}_{4}$ & $\mathrm{~K}_{5}$ & $\mathrm{~S}_{\mathrm{i}}$ & $\mathrm{R}_{\mathrm{i}}$ & $\mathrm{v}_{\mathrm{i}}$ \\
\hline $\mathrm{K}_{1}$ & 1 & 9 & 9 & 9 & 9 & 6.561 & 5.78 & 0.60 \\
$\mathrm{~K}_{2}$ & 0.111 & 1 & 3 & 5 & 3 & 4.995 & 1.38 & 0.15 \\
$\mathrm{~K}_{3}$ & 0.111 & 1 & 1 & 7 & 1 & 0.777 & 0.95 & 0.10 \\
$\mathrm{~K}_{4}$ & 0.111 & 1 & 1 & 1 & 3 & 0.333 & 0.80 & 0.08 \\
$\mathrm{~K}_{5}$ & 0.111 & 1 & 1 & 1 & 1 & 0.111 & 0.64 & 0.07 \\
\hline$\sum$ & & & & & & $\mathbf{9 . 5 5}$ & $\mathbf{1}$ \\
\hline
\end{tabular}

Source: Authors

Results of a pairwise comparison evaluated according to survey results present value $v_{i}$ in a column of Table 4 . Conforming to (Table 3 ) and the $v_{i}$ weights, the greatest weight is the education creative tourism activity, resp. creative tourism activity is linked with education (in survey very strongly preferred as well), subsequently the funny and relaxation activities, authentic and unique activities and challenging activities (in survey results strongly preferred). These activities are approximately of the same weight $v_{i}$ (Table 4). 
Weighted normalized decision matrix $\mathrm{W}$ is presented in Table 5. Table 5 presents the ideal $H_{j}$ solutions, which present the highest values of each criterion and $D_{j}$ solutions, which present the lowest values of each criterion. The resulting values $c_{i}$ are shown in Table 6.

Table 5 Weighted normalized decision matrix W

\begin{tabular}{clllll}
\hline Activity & $\mathrm{K}_{1}$ & $\mathrm{~K}_{2}$ & $\mathrm{~K}_{3}$ & $\mathrm{~K}_{4}$ & $\mathrm{~K}_{5}$ \\
\hline $\mathrm{a}_{1}$ & 0 & 0.061 & 0 & 0.046 & 0 \\
$\mathrm{a}_{2}$ & 0.245 & 0.061 & 0.05 & 0 & 0.029 \\
$\mathrm{a}_{3}$ & 0 & 0 & 0 & 0.046 & 0 \\
$\mathrm{a}_{4}$ & 0.245 & 0.061 & 0 & 0 & 0.029 \\
$\mathrm{a}_{5}$ & 0 & 0.061 & 0.05 & 0.046 & 0 \\
$\mathrm{a}_{6}$ & 0.245 & 0 & 0 & 0 & 0.029 \\
$\mathrm{a}_{7}$ & 0.245 & 0.061 & 0.05 & 0 & 0.029 \\
$\mathrm{a}_{8}$ & 0.245 & 0.061 & 0 & 0 & 0.029 \\
$\mathrm{a}_{9}$ & 0.245 & 0 & 0.05 & 0 & 0.029 \\
\hline$v_{i}$ & 0.60 & 0.15 & 0.10 & 0.08 & 0.07 \\
$H j$ & 0.245 & 0.061 & 0.05 & 0.08 & 0.029 \\
$D j$ & 0 & 0 & 0 & 0 & 0 \\
\hline
\end{tabular}

Table 6 Relative closeness of each alternative to the ideal solution

\begin{tabular}{cccc}
\hline Activity & $d_{\mathrm{i+}}$ & $d_{i-}$ & $c_{i}$ \\
\hline $\mathrm{a}_{1}$ & 0.795 & 0.077 & 0.088 \\
$\mathrm{a}_{2}$ & 0.077 & 0.259 & 0.771 \\
$\mathrm{a}_{3}$ & 0.797 & 0.045 & 0.053 \\
$\mathrm{a}_{4}$ & 0.089 & 0.257 & 0.743 \\
$\mathrm{a}_{5}$ & 0.793 & 0.089 & 0.101 \\
$\mathrm{a}_{6}$ & 0.114 & 0.247 & 0.684 \\
$\mathrm{a}_{7}$ & 0.077 & 0.259 & 0.771 \\
$\mathrm{a}_{8}$ & 0.095 & 0.253 & 0.727 \\
$\mathrm{a}_{9}$ & 0.100 & 0.251 & 0.715 \\
\hline \multicolumn{4}{c}{ Source }
\end{tabular}

Multi-criterion analysis using the TOPSIS method, evaluate five criteria. These criteria were ranked according to the TOPSIS method (Table 7). The best ranked creative tourism activities are courses, then events and least attractive events.

Table 7 Tourism creative activities results

\begin{tabular}{|c|c|c|c|}
\hline Ranking & Activity & Activity description & $\mathrm{c}_{\mathrm{i}}$ \\
\hline 1. & $\mathrm{a}_{2,} \mathrm{a}_{7}$ & $\begin{array}{l}\text { Courses of traditional crafts and folk art } \\
\text { Visual Art Courses }\end{array}$ & 0.771 \\
\hline 2. & $a_{4}$ & Cooking courses of cooking local dishes and meals & 0.743 \\
\hline 3. & $a_{8}$ & Workshops designed for children & 0.727 \\
\hline 4. & $a_{9}$ & $\begin{array}{l}\text { Courses of recycling and production of organic products } \\
\text { (Eco-friendly products) }\end{array}$ & 0.715 \\
\hline 5. & $a_{6}$ & Scenic Art Courses & 0.684 \\
\hline 6. & $a_{5}$ & Events associated with demonstrations of authentic folklore & 0.101 \\
\hline 7. & $a_{1}$ & Events with the theme of traditional crafts and folk art & 0.088 \\
\hline 8. & $a_{3}$ & Gastronomic events with the theme of cooking local dishes and meals & 0.053 \\
\hline
\end{tabular}




\section{CONCLUSION AND DISCUSSION}

The paper evaluates selected creative tourism activities in the Slovak Republic using TOPSIS methodology considering evaluation criteria. These creative tourism activities were evaluated according to the realized survey, where respondents figured out the most important criteria, which met the requirement of creative tourism activity.

The research results show that creative tourism activities should be primarily educational. Strongly important for respondents are activities that are funny, relaxing, authentic and unique and challenging. Respondents did not confirm the need to link creative tourism activities to a destination.

These results confirm the importance of support to creative tourism activities that are linked to education, for example courses of traditional crafts and folk art, unconventional cooking courses, scenic art courses and visual art courses (Table 7) in the Slovak Republic. To the contrary, creative tourism activities should "allow tourists to learn more about the local skills, expertise, traditions and unique qualities of the places they visit" (Richards \& Wilson, 2006), so it is a challenge for the supply side (in Slovak destinations) to provide courses connected with local culture, heritage and local people and improve local development through creative tourism's development opportunities.

Table 8 evaluates the creative tourism activities in relation to the theoretical background more described in the introduction. Activities targeting different kinds of courses also meet the conditions (Tan et al. 2013) of creative experiences as consciousness, motivation, creativity, and learning.

Table 8 Creative tourism activities evaluation in relation to the theory

\begin{tabular}{|c|c|c|}
\hline Activity & Tourism Experience & Influence \\
\hline $\begin{array}{l}\text { - Cooking courses of cooking } \\
\text { local dishes and meals } \\
\text { - Workshops designed for } \\
\text { children } \\
\text { - Courses of recycling and } \\
\text { production of organic products } \\
\text { (Eco-friendly products) }\end{array}$ & $\begin{array}{l}\text { - Reward } \\
\text { - Refreshment } \\
\text { - Happiness } \\
\text { - Liveness } \\
\text { - Enthusiasm } \\
\text { - Liveness }\end{array}$ & $\begin{array}{l}\text { - Involving tourists in the creative life } \\
\text { - Means of strengthening identity and } \\
\text { distinctiveness } \\
\text { - Form of edutainment } \\
\text { - Source of recreating and reviving the } \\
\text { domestic culture }\end{array}$ \\
\hline $\begin{array}{l}\text { - Scenic Art Courses } \\
\text { - Visual Art Courses }\end{array}$ & $\begin{array}{l}\text { - Freedom } \\
\text { - Nostalgia } \\
\text { - Enthusiasm } \\
\text { - Excitement }\end{array}$ & $\begin{array}{l}\text { - Involving tourists in the creative life } \\
\text { - Form of self-expression/discovery } \\
\text { - Form of edutainment }\end{array}$ \\
\hline $\begin{array}{l}\text { - Events associated with } \\
\text { demonstrations of authentic } \\
\text { folklore (folk art) } \\
\text { - Gastronomic events with the } \\
\text { theme of cooking local dishes } \\
\text { and meals }\end{array}$ & $\begin{array}{l}\text { - Recognition } \\
\text { - Refreshment }\end{array}$ & $\begin{array}{l}\text { - Creative means of using existing } \\
\text { resources } \\
\text { - Means of strengthening identity and } \\
\text { distinctiveness } \\
\text { - A source of, „atmosphere for the place“ } \\
\text { - Source of recreating and reviving the } \\
\text { domestic culture }\end{array}$ \\
\hline
\end{tabular}

The global tourism market has been experiencing immense changes in the last decade, mainly due to the globalization and technological advances both in terms of demand and supply. Changes are creating a lot of new opportunities as well as challenges for all tourism stakeholders (Palencikova, 2018). 
By knowing which activities attract tourists the most, tourists can maximize their creative experience by searching for what they want from the range of creative tourism experiences on offer. The paper also describes the key elements that can increase the level of creativity in the creative experience process, and the most important criteria for the demand side that creative activities should fulfill. Since there are relatively few studies examining these issues in the Slovak Republic, the current research aims to address these gaps in the current literature.

In order to understand the origins of creative tourism demand, in the Slovak Republic we looked at the tourism consumption. Creative tourism is not largely expanded in the Slovak Republic. There is a good tourism development in the Slovak Republic, but edification, resp. propagation of creative tourism must be improved; both in terms of demand (information dissemination) and supply (information dissemination, activities that attract tourists) as well. As research shows, to ensure the competitiveness of the Slovak Republic in the creative tourism market on the supply side, the Slovak creative tourism industry needs to focus mainly on courses and workshops (courses of traditional crafts and folk art, visual art courses, cooking courses of cooking local dishes and meals) and not focus only on events. Tourists tend to benefit from learning new skills; the activities of the creative tourism should be directly oriented towards authentic experience, knowledge dissemination, connected with the local community, but not necessarily connected with location or destination.

In the future research, authors will focus on concrete courses, workshops, and activities that attract and interest tourists in concrete tourist regions. Future research on creative tourism development should also involve opinions of destination management organizations, that represent the "orgware" of creative tourism supply and in-depth interviews with their managers. Furthermore, understanding the preferences of creative tourists and specifics of creative supply in various tourist regions within Slovakia may serve to achieve greater acceptance of creative tourism as a new form of tourism development in Slovakia and include creative tourism in tourism development strategies in the near future.

Acknowledgment: The paper is a part of the research done within the project VEGA 1/0169/18.

\section{REFERENCES}

Billing, P. \& ODell, T. (2010). Experiencescapes: Tourism, culture and economy. Copenhagen: Copenhagen Business School Press.

Burleson, W. (2005). Developing creativity, motivation, and self-actualization with learning systems. International Journal of Human-Computer Studies, 63 (4-5), 436-451. doi:10.1016/j.ijhcs.2005.04.007

Carvalho, R.M.F., Martins da Costa, M.C. \& Ferreira, A.M.A (2019) Review of the theoretical underpinnings in the creative tourism research field. Tourism \& Management Studies, 15 (SI), 11-22.

Coelho, M., Gosling, M. \& Almeida, A.S.A. (2018) Tourism experiences: Core processes of memorable trips. Journal of Hospitality and Tourism Management, 37 (1), 11-22.

Csapo, J. (2012). The Role and Importance of Cultural Tourism in Modern Tourism Industry. Strategies for Tourism Industry - Micro and Macro Perspectives, 201-232. doi:10.5772/38693

Cutler, S.Q. \& Carmichael, B. (2010). The dimensions of customer experience (M. Morgan, P. Lugosi, \& J.R. Ritchie, Eds.). In The Tourism and leisure experience: Consumer and managerial perspectives, 3-26. Bristol: Channel View.

Hanifl, B. (2015). What is the economic value of Creative Tourism in Santa Fe, New Mexico? Retrieved from: https://core.ac.uk/download/pdf/36693356.pdf. Accessed on: 1 July 2019 
Hrubalova, L. \& Palencikova Z. (2017). Demand for Creative Tourism in Slovakia. In: SGEM 2017: Modern science: Conference proceedings (Economic \& tourism, Vol. IV, STEF92 Technology, pp. 205-221). (2017). Albena, Bulgaria.

Ivcevic, Z. \& Mayer, D.J. (2009). Mapping dimensions of creativity in the life-space. Creativity Research Journal, 21, 152-165.

Jelincic, D.A. (2009). Splintering of Tourism Market: New Appearing Forms of Cultural Tourism as a Consequence of Changes in Everyday Lives. Coll. Antropol, 33 (1), 259-266.

Kaufman, J.C. \& Baer, J. (2012). Beyond new and appropriate: Who decides what is creative? Creativity Research Journal, 24, 89-91.

Maisel, E. (2009). Bridging the artist-tourist gap (R. Wurzburger, T. Aegeson, A. Pattakos, \& S. Pratt, Eds.). In Creative Tourism. A global conversation, 171-182, Santa Fe, New Mexico: Sunstone Press.

Maitland, R. (2008). Conviviality and everyday life: The appeal of new areas of London for visitors. International Journal of Tourism Research, 10, 15-25.

Palencikova, Z. (2018) Creative Tourism Development in Slovakia and its Potential for Strengthening the Tourism Destination Competitiveness. (Csapó, J., Gerdesics, V., Töröcsik, M. Eds.) In Generációk a turismusban, Nemzetközi turizmusmarketing konferencia, Pesc, Hungary: Pécsi Tudományegyetem, 531-541.

Pine, B.J. \& Gilmore, J.H. (1998). Welcome to the experience economy. Boston, MA: Harvard Business Review Press.

Raymond, C. (2007). Creative tourism New Zealand (G. Richards \& J. Wilson, Eds.). In Tourism, Creativity and Development, 145-158. London, United Kingdom: Routledge.

Richards, G. \& Marques, L. (2012). Exploring Creative Tourism: Editors Introduction. Journal of Tourism Consumption and Practice, 4 (2), 1-11. Retrieved from: https://www.researchgate.net/publication/241886393_ Exploring_creative_tourism_Introduction Accessed on: 1 July 2019

Richards, G. \& Raymond, C. (2000) Creative tourism. ATLAS News, 23,16-20.

Richards, G. (2013). Tourism Development Trajectories. The Routledge Handbook of Cultural Tourism, 330331. doi: $10.4324 / 9780203120958$.ch37

Richards, G. \& Wilson, J. (2006). Developing creativity in tourist experiences: A solution to the serial reproduction of culture?. Tourism Management, 27, 1209-1223.

Saaty, T.L. (1996). The analytic hierarchy process: Planning, priority setting, resource allocation. Pittsburg, PA: RWS.

Tan, S., Kung, S. \& Luh, D. (2013). A Model Of 'Creative Experience' In Creative Tourism. Annals of Tourism Research, 41, 153-174. doi:10.1016/j.annals.2012.12.002

The Analytic Hierarchy Process. (n.d.). Retrieved from: http://www.dii.unisi.it/ mocenni/Note_AHP. Accessed on 25 June 2019

UNESCO. (2006). Towards sustainable strategies for creative tourism: Discussion report of the planning meeting for 2008 international conference on creative tourism Santa Fe, New Mexico. Retrieved from: https://unesdoc.unesco.org/ark:/48223/pf0000159811. Accessed on 24 June 2019

Wachowicz, T. (2011). Application of Topsis Methodology to the Scoring of Negotiation Issues Measured on the Ordinal Scale. GIGLIOTEKA NAUKI, 6, 238-260. Retrieved from: http://yadda.icm.edu.pl/yadda/element/ bwmeta1.element.ekon-element-000171230805. Accessed on: 28 June 2019

\section{EVALUACIJA KREATIVNIH AKTIVNOSTI NA OSNOVU TOPSIS- ZASNOVANOG ALGORITMA ZA PODRŠKU ODLUKAMA}

Glavni cilj ovog rada je evaluacija kreativnih aktivnosti uz pomoć algoritma za podršku odlukama zasnovanom na TOPIS metodi. Kao što su Cutler \& Carmichael (2010) definisali, turistička iskustva ostaju u sećanjima, prethode im motivacija i očekivanja a rezultiraju u zadovoljstvu ili nezadovoljstvu. Kreativni turizam još uvek nije dovoljno razvijen u Republici Slovačkoj, i nema teoretskih dokaza za vrstu aktivnosti u kreativnom turizmu za koje bi turisti bili najzainteresovaniji. Kako rezultati pokazuju, turisti preferiraju one aktivnosti kreativnog turizmna koje su povezane sa obrazovanjem. Rezultati takođe pokazuju da turisti ne povezuju kreativne aktivnosti sa turističkim destinacijama, što bi trebalo da rezultira u boljoj ponudi u budućnosti, uz podršku lokqalne ekomonije i održivosti, uključujući zanatstvo, umetnost i lokalanu kulturu.

Ključne reči: kreativni turizam, turistički razvoj, konkurentnost, TOPSIS 